\section{A view from the window}

\author{
Gary K. Meffe
}

I begin my first assignment for this journal as Deputy Editor for North America with a great deal of excitement and a healthy dose of trepidation. I have the unexpected honour of offering to the rest of the world a North American perspective on contemporary conservation issues every three months, and I feel a childlike excitement at the prospect. But I also feel the sober weight of responsibility to represent accurately the manifold views, notions, events and biases of the large and diverse conservation community on the west side of the Atlantic. Where to begin such a challenge is daunting.

The answer, I think, may lie right outside my window, here at the Savannah River Ecology Laboratory near Aiken, South Carolina. You see, my immediate environs nicely illustrate several stark contrasts of relevance to anyone in this field; contrast between the past and future, between destruction and rebuilding, between exploitation and conservation, and between where America has been and the many choices that lie ahead. For the laboratory where I work, which is run by the University of Georgia, sits on $770 \mathrm{sq} \mathrm{km}$ of territory known as the Savannah River Site (SRS). The SRS is a federally run nuclear production facility of the US Department of Energy, which for nearly 40 years produced plutonium and tritium used in much of the nuclear warhead arsenal of the USA. It was, and is, a product of the cold war. What does this have to do with Oryx and conservation? A lot, I think.

As I gaze across the parking lot I see the familiar, if rather ugly sight of steam pipes, power lines (complete with large orange balls to warn helicopters of the potential entrapment that lies there), and countless signs with security slogans and safety warnings. If I look further I see even-aged pine forests and clearcuts, managed by the US Forest Service for timber production. Beyond that, some 24 $\mathrm{km}$ distant, I see the first of five ageing nuclear reactors, 1950s vintage, now idle and waiting an unknown and undetermined fate.
(In a bit of poetic irony, upon one of these reactors a flock of vultures normally sits, quietly surveying the countryside as though wondering what to do now with this unusually large road kill under their talons.) I see support facilities housed in dreary government buildings - more artefacts from a very different time that was only yesterday. I see untold amounts of deadly nuclear waste awaiting peaceful disposition to a final resting site for the next several millennia. I see a clean-up carrying a price tag of some $\$ 100$ billion.

But encompassing it all I see $770 \mathrm{sq} \mathrm{km}$ of land, much of which is in excellent condition, protected from the malignancy of shopping malls, condominiums, golf courses and convenience stores by a government that said, 'Keep Out' for four decades. I see streams in much better condition than they would otherwise be because their drainages have been protected from chain saws and agricultural chemicals. In those streams I can see endemic mussels, and the highest diversity of freshwater insects yet recorded in North America. I see an intact, native fish fauna with no exotic species, a rarity these days anywhere in the USA. I see extraordinarily high herpetological diversity and many rare species. I see healthy plant communities in wetlands called Carolina Bays, and I see turtles, salamanders and frogs by the thousands coming annually to those bays to reproduce or feed. Most of all, I see a glimmer of hope. For, amidst all the industrial development, amidst the potentially unthinkable levels of destruction the products of the SRS represent, there is a bold, positive reminder that humanity and nature can, indeed must, coexist.

The SRS is a microcosm for the nation and the world, because it represents the difficult choices that must be made as we move from a world polarized by political ideologies to one unified by ecological connectedness. It is also a grim reminder of how much humanity has to change to correct its past errors and save what is rapidly diminishing of its natural heritage. This site provides an inkling of the many tough choices ahead for humanity. How do we abandon an industrial-military economy in favour of more benign technologies? How do 
you put the many genies back into their bottles? Will we pursue co-operation rather than confrontation and domination? If so, do we even know how? Can we invest in peace, environment and the long-term future rather than the domination of one another and of the Earth? Do we have a choice?

It is these types of issues that I hope to address in the coming months. I wish to pursue the philosophical and ethical underpinnings, from a North American perspective, that seem necessary to guide humanity through the rough waters of change as we fundamentally alter the way we must do business with and on the Earth. I believe that here in North America great and fundamental changes will be necessary in the relationship between humans and the Earth if our collective future is to hold much promise for things wild and free, and the ecosystems upon which they and we depend. Our apparently suicidal refusal to acknowledge and then deal with the human population juggernaut is primary on the list. If we cannot come to grips with that, I believe the world will be a much uglier place; endan- gered species may well be the least of our worries when eight billion bodies crowd the planet. Second, our worship of growth economies, continual expansion, materialism, and increased living standards will complete the task if sheer numbers do not. An ethical bankruptcy that favours short-term profit over long-term stability, and amusement parks and mega-malls over a holistic land ethic will continue to make us all poorer of soul, if richer of body for a few. These trends and others like them will continue to destroy the species and ecosystems that appear in these pages and in similar journals. The view from each of our windows is telling, and continually changes. Some of the changes are positive, while many others continue to degrade nature and the human condition. The view out of my own window offers both hope and a challenge hope that humanity and nature can co-exist on a larger scale, and a challenge for all of us to determine how that can be done. It will not be easy, but it may well be the most important thing humanity has ever done.

\section{NEWS AND VIEWS}

\section{Gerald Durrell OBE: 1925-1995}

Gerald Malcolm Durrell was born on 7 January 1925 in India, but when his father died in 1928 the family started a peripatetic life that eventually brought them to rest on the Greek island of Corfu, where they stayed until the outbreak of World War II. It was on Corfu that the Greek biologist Theodore Stephanides taught the young Gerry and had a profound influence on his future life. After attempts at schooling in wartime England he gained a position as a student keeper at the Zoological Society of London's Whipsnade Zoo Park. A legacy of $£ 3000$ in 1947 (a significant sum in those days) enabled him to finance the first of his many collecting trips. And the rest is history ... at least it is all pretty well documented in his 37 books.

After his third expedition to Africa, in 1950, he commenced writing and broadcasting, cul- minating in his first book, The Overloaded Ark, which was published in 1953. It was an immediate success and the income from his writing was to finance a series of collecting expeditions written up in the books that followed. The Bafut Beagles, published in 1954, is my personal favourite and encapsulates Durrell's ability to observe human foibles and to anthropomorphize wildlife but never sentimentalize it. And, of course, his robust sense of humour is omnipresent. In 1951 he married Jacqueline Rasen and she accompanied him on many of his collecting, and later filming, expeditions until the marriage was dissolved in 1979. His second wife, Lee McGeorge, accompanied him on most of his later travels and also co-authored books with him.

In 1959 he founded Jersey Zoological Park, which rapidly became transformed into a conservation-based collection under the auspices of the Jersey Wildlife Preservation Trust 